\title{
Laughter in the Old Testament: A hotchpotch of humour, mockery and rejoicing?
}

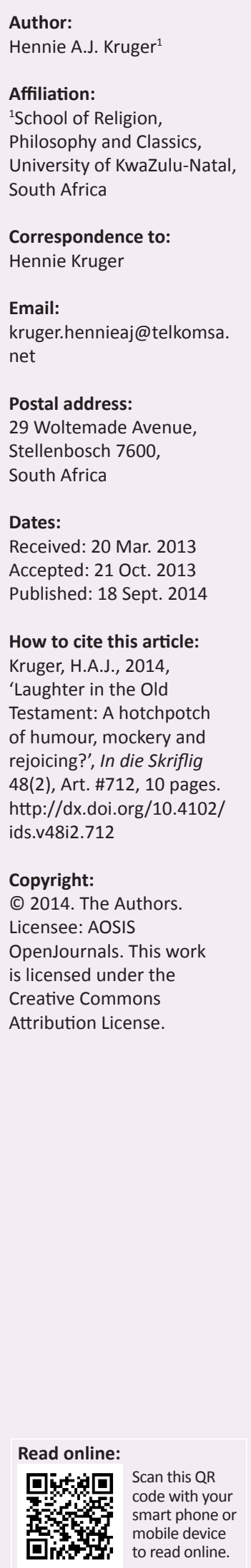

Aspects of humour appearing in society, religion, literature and speech have been discussed. The article investigated in particular the current tendency to interpret certain passages in the Bible as evidence of humorous traits. In these cases humour is taken as an interpretative key. A prerequisite to provide a hermeneutical basis for reading the Old Testament in terms of humour has been discussed. A few texts that present Yahweh as laughing have been considered.

Lag in die Ou Testament: 'n Mengelmoes van humor, bespotting en vreugde? Aspekte van humor wat in die gemeenskap, godsdiens, literatuur en omgangstaal voorkom, word bespreek. Die artikel gee veral aandag aan die huidige neiging om sekere tekste in die Bybel as voorbeelde wat humoristiese trekke vertoon, te verstaan. In sulke gevalle word die humorbegrip as 'n interpretasiesleutel hanteer. Die voorvereiste vir ' $n$ hermeneutiese basis om die humorbegrip in die Ou Testament te verstaan, word bespreek. Enkele tekste waarin verwys word na die Here wat lag, word ook ondersoek.

\section{Introduction: The claim that humour features in the Bible}

It would appear that many people who read the Bible take the view that it accommodates humour, but what is the factual situation? The issue will be investigated regarding the meaning of terms expressing laughter or ridicule, including the meaning of some passages that are usually quoted by those who search for humour in the Bible.

\section{The interpretation of keywords in the Old Testament related to laughter and mockery}

The concepts of laughter or laughing (root $s h q$ and $s h q$ ) and mockery or mocking $\left(l^{\prime} g\right)$ are often understood as terms that express humour in the Bible. Bartelmus (2004; cf. Barth 1997:10) indicated that these concepts found expression in a variety of ways in the Old Testament. This includes a comparison of concepts in the same semantic field, their etymological background, synonyms, typical gestures accompanying the expressions, parallel terms and forms of metathesis. An example of the latter can be seen in the resemblance between ' $l g$ [stammering tongue] and $l^{\prime} g$ [ridicule] (Is 32:4; cf. Brown, Driver \& Briggs 1968). This phenomenon created a play on words, but in order to sharpen the author's intention with the particular word, it added a deliberate sting to the expressions.

According to Bartelmus (2004), the meaning of a lexeme (laughter or mockery) is determined by the lexeme itself, and in a lesser degree by its surrounding literary and/or theological context(s). The author of this article, however, accepts that the context plays a decisive role in determining the meaning of words and texts.

\section{The functioning of puns (play on words)}

Stinespring (1980) considers the pun as one of the most important bearers of humour in the Old Testament. However, he acknowledges that not all will agree with his choice of examples representing puns.

In this regard, Steinspring (1980:660) identified alleged hints of humour in puns regarding the creation of the first human beings ( $\mathrm{Gn} 2: 7 ; 2: 23 ; 3: 20$ ). The same applies to the Tower of Babel (Gn 11:9). He also finds this inclination in the names of the patriarchs (Abraham and ' $\mathrm{ab}^{\prime}$ - father; Gn 17:5, 17, 19; 21:6; 26:8), including that of Ishmael (cf. the word for 'hear', 'give heed'; 16:11; 17:20), Esau ('hairy'; Gn 25:25), Edom ('red'; Gn 25:30), Jacob ('heel' and 'supplanter'; 25:26; 27:36; Hs 12:2-3) and Joseph ('take away', āsaph; Gn 30:23; or 'add', yasaph; 
Gn 30:24). Manasseh suggests 'forgetfulness' (Gn 41:51) and Ephraim reminds of the word 'to be fruitful' (Gn 41:52; Hs 9:16; 14:8). Steinspring (ibid:660-661) also pointed out that the prophets often used puns with ironic, sarcastic or satirical force to make their monitory message more vivid. He admits that their humour is of a grimmer sort as that found in Genesis (cf. Am 5:5; 8:1-2; Hs 8:7; 12:11, 12). He also agrees that in some texts in Amos a very grim form of humour is expressed - there is no humour anymore, only deep pathos. ${ }^{1}$

\section{The concept of humour and exegesis or exposition}

According to Freedman (1992:325-333), scholars maintain that humour appears in different literary forms or styles. He reminds the reader that the Old Testament accommodates several words expressing laughing or laughter, whether in a spirit of goodwill or when ridiculing someone. However, he accepts the fact that the Old Testament does not contain any word that can be translated as 'humour' as the concept is understood in the contemporary Western society.

Consequently, readers and authors are confronted with exegetical and expository problems when applying humour as an interpretative key in their reading of the Old Testament. Note for example that a taunt against the nations, as presented in the Old Testament, can easily slip into blasphemy of their gods (Watts 1985:148). Compare the speeches in Isaiah 10:5-19, which have certain parallels in 36:4-10 and 13-20, and 37:10-13 and 24-25. The setting of these latter passages is that of siege and the preparation for negotiation. The setting of Isaiah 10:5-19 is more general, whilst the setting in chapters 36 and 37 belongs to the genre of battle taunts as in the case of Goliath and David. These examples in Isaiah 10 remind the reader of the words of Babel's residents and kings in Genesis 11:3-4, of Babylon's king in Isaiah 14:13-14, the people of Tyre in Ezekiel 27:3 and 28:2, Egypt in Jeremiah 46:8, and Edom in Obadiah 3.

The reader, who claims to have identified texts or passages apparently disclosing terms with humorous content, is firstly compelled to follow exegetical guidelines to investigate relevant words or passages. The following discussion deals with this problem.

\section{A few attempts by authors to interpret the Old Testament in a humorous mode The tower of Babel}

Thielicke (1975:106-108) alleges that, should the episode depicting God descending from heaven to inspect the building of the Tower of Babel (Gn 11:1-9) not be understood as humour, he admits that he does not know what humour Zechariah 9:5. actually means. He finds it hilarious that God comes down from heaven to inspect an attempt of humankind's selfaggrandisement to become like God. De Villiers (2000:17, $20,21)$ compiled a number of incidents with ironical twists, relating these events to the idea that God has a sense of humour. He defines the narrative about God descending from heaven to inspect the activities of humankind as 'high humour'. Nonetheless, Greenstein (1992:331) maintains that the episode of the Tower of Babel is not necessarily funny. Thus, some find humour in these passages, whilst others deny it.

The most heinous of sins, humankind's desire to become like God (Gn 3:5b), may actually be the issue dealt with in the narrative about the Tower of Babel. Thus understood, the passage is concerned with humankind rising up against God. However, the passage may have relevance to, or a connection with, the Babylonian exile. The scene is set in Shinar, that is, Babylonia (cf. Gn 11:2). It may be an announcement of God that attempts by Babylonian kings to oppress the whole of the Near East will be thwarted, whilst they and their subjects will be scattered far and wide. On the other hand, it may represent a motivation for the extant variety of languages in the Near East. God created confusion amongst the inhabitants by thwarting their understanding of one another's language. The narrative may thus serve as a weapon to attack the arrogance and power of Babylon. As Harrison (1978:224-225) has indicated, puns are often understood as instruments of derision. Thielicke does not consider this fact. Neither does he take into account the related narrative that describes God's descent to inspect the situation at Sodom and Gomorrah. The same verb functions in both cases (yrd - Gn 11:5, 7; 18:20, 21). This position is further substantiated by Exodus 3:8, a text that refers to God descending to free the people of Israel from Egyptian bondage. The narratives deal with God's acts of salvation joking is not the issue.

According to Wenham (1987:241), the name Babel resembles a typical aetiological formula with it being rather loosely tacked onto the preceding narrative. However, the repeated phonetic allusions to Babylon in the previous verses make this an untenable option. The narrative serves to explain the word Babel and to characterise it as being under divine judgement.

The Babylonians understood Babel as 'the gate of the god' (Von Rad 1978:150). The Hebrews preferred (Van Selms 1967:164) the meaning 'stir-up', 'mix-up', 'confuse' or 'medley'. Wenham (1987:241-242) reminds the modern reader that here, as is often the case in the Old Testament, it is clear that the etymology offered is a popular one - an interpretation of a name based on a similar sounding word, and not a scientific etymology explaining the verbal roots. Compare the name Moses, which sounds like the verb used for pulling him from the water (Ex 2:10), and Samuel

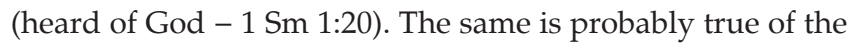
Babylonians' own etymology of the phrase the gate of the god. 
The word bālal (qal pf.; cf. the Afrikaans word babbel) with the meaning 'mix-up' occurs in verse 9 and in verse 7 (wěnābělāh - qal impf.). In sacrificial law it apparently means 'smear' or 'moisten' with oil (Lv 2:4).

\section{Abraham and Sarah}

In his survey of narratives in the Bible that, in his view, display a humorous intent, Critchley (2002:41-42) purported to have found examples of the phenomenon in, amongst others, the episodes dealing with the promise of Sarah's pregnancy and the birth of Isaac at a time when Sarah was over the usual age to have children (Gn 17:4-5). He surmises that since both Abraham (Gn 15:4) and Sarah laughed (Gn 18:12-13) at the prospect of a new birth announced by God, they showed a sense of humour (Gn 17:17). He concludes that God must have a sense of humour too, since he gave Abraham's son a name associated with laughter.

In contradistinction to this view, it seems clear that God's command to Abraham, namely to call the boy 'Isaac' (yișhāq), serves his plan of joyful salvation in the future for his people, Israel. It does not represent a personal characteristic of God's divinity. Secondly, if Sarah's laughing at the prospect of having a child of her own at that age should be understood as an innocent humorous gesture, why did the Lord make an issue of the matter and questioned (or reprimanded) her laughing at all? (Gn 18:10-15). The biblical text judges Sarah's laughter as mocking the Lord's promise. The word sh $h q$ is associated with three women in embarrassing situations Sarah in Genesis 21:6; Rebecca in Genesis 26:8; Potiphar's wife in Genesis 39:14, 17.

Thus, as an expression of religiosity, this word portrays the patriarch's unbelief (Gn 17:17; 18:13; 21:6). According to Genesis 21:6, Sarah becomes the laughing stock of her neighbours. However, the Hebrew words reveal something peculiar about this expression: 'Laughing with Sarah' when translating the use of the preposition ' $l e$ ' as 'to laugh with' (plus 1st person singular). On the other hand, the use of a different preposition (be) results in a different meaning: 'to laugh at', as in the case of Genesis 39:14 and 17. In the latter text, Pharaoh's wife accuses Joseph of mocking the royal household (Van Selms 1967:10-11; cf. Gispen 1979:211). It is noteworthy that the common word for laughter (root: $s h q$ ) is used in Genesis 39:14 and 17, but with the meaning of 'derision'.

However, in Genesis 21:6, the LXX did not translate śhq with the usual gelaô (gelôta), but with sugchareitai moi [everyone will rejoice with (or congratulate) me], thus perhaps slightly toning down the idea of Sarah being too harshly ridiculed (Beuken 1961:129). Referring to Sarah's attitude in Genesis 18:12-13, Rengstorf (1985), however, claims that the note of scorn is stronger in the Septuagint (cf. Lm 1:7).

It would appear then that, in the first instance, Sarah uttered a laugh of unbelief, whilst in the second she laughed at the prospect of having her own child. The laughter dominating the latter episode is marked by her neighbours joining in with her laughter - jokingly mocking her, so to speak.

Returning to Critchley's discussion (2002:41-42), it has to be said that his transcription of the Hebrew name 'Isaac' as Isha-ak, instead of yishāq (Gn 17:19) discloses a misunderstanding. In addition, he extracts the syllables $\mathbf{A H}$ or HA from AbrAHam, or AbraHAm, and SarAH, using these components in inverted form as a basis for what he judges to be an onomatopoetic 'ha-ha', the sound of someone laughing. However, it seems unattainable to attempt the creation of words and phrases by arranging combinations of selected letters or syllables of a receptor language (in this case English) in a hypothetical way, whilst projecting the meanings, thus established onto letters or syllables of the original language concerned (in this case Hebrew; cf. Pierson 1994:331).

In contrast to Critchley's (2002) view, it has to be stated that the two letters $\mathrm{AH}$ or HA form an integral part of the two personal names, which can only be understood in relation to the rest of the letters and words surrounding them ('father of a multitude of nations' and '[female] sovereign' or 'empress'; cf. Brown et al. 1968). The vowels of the two words, as they appear in the two personal names in Hebrew, do not have the same appearance and value which allegedly equal their use in a Western language, namely English. Contrary to this attempt, the laughter mentioned in the text actually refers to unbelief and then to the joy of a new birth, especially the initial realisation of God's covenant with Abraham, namely that the number of his offspring, will be great (Gn 15:5).

In addition, the nearest one may come to associate laughter with syllables can perhaps be gleaned from the interjection $h e^{\prime} \bar{a} h$ of which $\mathrm{H}$ and A vaguely resemble the way letters are put together to form words as suggested by Critchley (2002:41-42). However, according to Hebrew lexicons (Brown et al. 1968), it serves as an expression of enjoyment (Aha!) and is always introduced by 'âmar [he/she says] (Is 44:16, cf. v. 17) - also of satisfaction over the misfortune of an enemy or rival (Ps 35:21, 25; 40:16; 70:4; Ezk 25:3; 26:2; 36:2) and, metaphorically, of the neighing of a war horse in battle (Job 39:24-25). Incidentally, according to Sinclair (1995:645), the word laugh can also be used in connection with the sound produced by animals like mammals and birds. However, no connection exists between this term and the names of Abraham, Sarah or Isaac.

Rees (2001:54.2) refers to Job 39:24-25 and quotes from a Bible version that translates $h e^{\prime} \bar{a} h$ as ' $\mathrm{Ha}, \mathrm{Ha}^{\prime}$, imagining a horse laughing. Bible versions oscillate in their translation of this word between 'Ha-Ha' and 'Aha'. Even if 'Ha-Ha' were an acceptable translation, no relationship exists between the Hebrew terms used in Genesis 17:17 (Abraham's name) and Job 39:25 (the neighing of a horse [he' $\bar{a} h]$ ). However, the word he'āh does carry a mocking dimension. Ezekiel 25:3 and 6 (cf. Ezk 26:2; 36:2) links this term to the Ammonites mocking 
God's temple, the land of Israel and the people of Judah (cf. Is 44:16; Ps 35:21, 25; 40:16; 70:4).

Commenting on Ishmael's behaviour towards the baby, Isaac (Gn 21:6, 9), Brown (1978) suggested translating the verb sāhaq not with the usual meaning of 'laughing', but with 'mocking' in the sense of 'harmless teasing'. This is possible. The possibility also exists that the word may carry negative sexual associations or undertones in the sense of molesting when describing Ishmael's behaviour towards Isaac (Gn 21:9). This may be inferred partly on the basis of Isaac 'playing with', that is 'caressing' (měsaheq), his wife Rebekah (Gn 26:8). In the latter case, the word carries a positive meaning, but in both cases the word may have a sexually related inclination.

\section{Moses}

Goldman (1952:2) pointed out that the derivation of humour, that is, 'moisture' and the theory of the humours influencing human nature, was foreign to Bible authors. Yet, according to him, one of the praises of Moses, as related in Deuteronomy $34: 7$, is that at the age of 120 years, 'his eye was not dimmed and his humour had not fled'. The word translated as 'humour' here is to be understood as 'sap' or 'vigour'.

However, things become complicated when it is realised that in the same text the word 'ênô, apart from meaning 'eye', can also be translated as 'spring' (of water). In addition, the last word in the text, understood as 'his strength', can also be translated as 'his moisture' or 'freshness'. If one reads the text as 'his spring (of water) did not dry up nor did his moisture/ freshness flee', unnecessary confusion might be created. The meaning of the text is probably that Moses's eyes were still in good condition in spite of his high age. The text does not deal with humour, but there may linger something in the background related to Moses having been drawn from the water when he was a baby (Ex 2:10).

\section{Judges}

Although Greenstein (1992:331) admits that humour is notoriously difficult to identify and that definitions of types of humour vary, he nevertheless considers the narrative of the Israelite judge, Ehud, slaying the Moabite king, Eglon (Jdg 3:15-30), as a story with a comical trait. He avers that Ehud's left-handedness and the accompanying abnormal handling of his sword served as the key to the killing. The stabbing of Eglon that caused an odour to rise from his bowls, confused his servants and lead them to believe that their master was relieving himself. Several texts in the Old Testament refer to left-handedness. According to Judges 3:15 and 20:16, some soldiers were left-handed, thus impeded on the right-hand side. However, Ehud, although left-handed, could operate successfully in slaying Eglon. Thus, he was able to perform this deed in spite of his problem. Other soldiers are depicted as ambidextrous and never missing a shot with a slingshot (1 Chr 1:12).
Another attempt to classify a case in Judges as humorous comes from Pierson (1994:332). He states that the Bible sometimes makes history humorous. Compare Judges 1:5-7, where Adonibezek who has made 70 captive kings with thumbs and great toes cut off pick up food under his table like dogs, had his own hands feet maimed in exactly the same fashion.

The book of Judges was, however, constructed and compiled according to a pattern of rise and decline in the religious and political situation of the tribes of Israel. All the narratives dealing with the individual judges developed in this pattern (Jdg 2:11-21; Claassens 2008). The tales describe the tribes' inconsistent behaviour towards God. In this light, it is difficult to understand why this particular narrative of Ehud has something comical attached to it. The problem with Greenstein's approach, and other viewpoints with a similar tenor, is that these arguments disqualify themselves by confusing brutal murder with humour.

Huxley's remark seems appropriate here: 'Death ... It's the only thing we haven't succeeded in completely vulgarizing' (Daintith \& Stibbs 1994:181, n. 83). In addition, this problem is highlighted by the fact that the Old Testament contains several narratives dealing with violence, to such an extent that it may be identified as 'a bloodstained book' (Theron 2004:119). God himself exterminated whole nations (cf. the books of Joshua, Judges and Samuel). The latter represents a trajectory running throughout the Old Testament.

Gunn and Fewell (1993:63-68, 175-181) identified cases of humour in the narrative of Samson (Jdg 13), particularly the case of Manoah, his wife and the angel (messenger). According to them, the messenger has a wonderful sense of humour. This characteristic is then illustrated by the way he deals with the two individuals (Gunn \& Fewell ibid):

Is he acting independently on Yahweh's behalf, or is he a direct reflex of God, a manifestation of the divine? Is it then Yahweh who has the sense of humor? (p. 68)

Apart from the vagueness of their suggestion about any humour being present in the said passage, they take a huge leap by projecting the idea of humour onto the personality of Yahweh. Thus, this attempt represents another case where an allusion is superimposed onto the text without providing a sound hermeneutical basis.

Other examples cited by Greenstein (1992) include incidents in the book of Esther, like the impalement of Haman as well as forms of irony or sarcasm (Gn 37:19; Am 4:4-5), ridicule (Jdg 9:53-54; 2 Sm 11:21; Jdg 4-5; 1 Ki 18:27; Ps 44:24), satire (Is 44:9-20; Ezk 29:31; Nah 2; Dn 4; Is 14; Gn 3:9-13), parody (Es 1-3), trickery (Gn 12:10-20; 30:29-43; Jdg 3, 4, 7-8, 14-16), verbal wit (Gn 18:23-33; 40:19; Jr 2:12; Is 1:2), and proverbial humour (Pr 11:22; 26:17-19).

Apparently there is nothing to substantiate Greenstein's claim that these stories bear a humorous character. All 
the examples are interpreted in light of a contemporary method, which seems to ignore the contention of ancient biblical authors.

\section{Job}

Van Selms $(1983: 15,80,179,182,183,205)$ often refers to laughter as it appears in Job (cf. Job 22:19; 29:24; 39:10[7]; 39:20[17];22:25 [22]), without qualifying it as humour. Instead, as he has indicated elsewhere, Van Selms (1984:24-25) is convinced that Job deals with wisdom, or actually confronts the type of wisdom that teaches that sin instigates human suffering. Janzen (1985:17-18) restricts his discussion to irony only as it appears in Job. Habel (1985:49-53, 54-57) also confines his discussion to irony as a feature that hedges in, what he calls, the legal metaphor (cf. the chiastic pattern, Habel ibid:54).

\section{Psalms}

A similar problem arises in the case where two phrases in Psalms 60:8 are classified as humour, namely 'Moab is my wash-pot, over Edom will I cast out my shoe' (Rees 2001:54). The psalm, however, depicts God as being in control of all the territories mentioned (Edom, Moab amongst others; Ps $60: 6-10 ; 13-14)$ and states that he will hand over land to his people in spite of their doubts. Instead of God stating: 'In triumph I will parcel out Shechem', others translate it as: 'I want to exult', adding a tinge of joy to the action (Ps 60:6). However, humour is not considered in the texts referred to.

\section{Ecclesiastes}

According to the book of Ecclesiastes, several life situations may be considered as good. However, the author passes off these events as being meaningless and foolish (cf. Ec 2:1-16). It is striking that the term laughter (root: shq a keyword in this article) also appears on the list (Ec 2:2; cf. Pr 10:23, kiśhôq). Authors and readers may cite Ecclesiastes 2:2 or other texts to downplay the exercise of laughter in general. Ecclesiastes, however, deals with this topic on the basis that all things are futile. This outlook on life functions as a corrective on humankind's overestimation of the world (cf. Ec 1, 2, 4, 6, 7, $10)$, but it does not neutralise laughter in the rest of the Bible.

\section{Song of Songs}

Consider the words: 'My lover thrust his hand through the latch-opening; my heart began to pound for him' (Can 5:4, NIV). A few authors (cf. Rees 2001:54) regard this statement as a reference to sexual intimacy expressed in humorous mode. Yes, perhaps sexual intimacy, but what is humorous about the situation? Also, how does one reconcile this view with the reference following the statement in question about the beloved who arose to open for her lover only to find that he is not around and going out on the street looking for him, et cetera? Secondly, any interpretation of this text has to keep in mind that all references to the lovers (male and female) are clothed in metaphorical terms. Humour does not seem to function in this textual environment. Several examples of the lovers comparing one another to objects in nature expressed in metaphorical style, dominate the book. None of these comparisons seem to carry any humorous tendency. ${ }^{2}$

\section{Prophets \\ Ezekiel}

Berger (1997:188) lists some passages in the Bible that he considers examples of humour, although spiced with vulgarity. With reference to Ezekiel 4:12, he writes: '[The prophet] Ezekiel was commanded to eat excrement.' The fact of the matter is that God commanded Ezekiel to prepare his food using human excrement as fuel - not to mix it with his food. The Hebrew preposition 'be' attached to the objects, namely the balls of human excrement, indicates that the excrement was meant to serve as instrument to prepare the food (Aalders 1955:102). The latter statement is supported by the use of the preposition upon (' $l$ ) in Ezekiel 4:15, indicating that the prophet is instructed to prepare the food 'on' cow dung (Aalders ibid:104; Zimmerli 1979:171). The prophet reacted negatively against these injunctions on the basis of the purity laws (Ezk 4:14). Consequently God allowed him to substitute human excrement with cow manure as fuel for preparing his food (Ezk 4:15). The two symbolic actions may refer to a situation during a siege of Jerusalem or conditions during exile away from Jerusalem. ${ }^{3}$

This trend of thought coming from Berger represents either an oversight in reading the text concerned, which is doubtful, or - and this is more probable - the attempt represents another typical example of superimposing a foreign meaning onto a biblical text.

\section{Daniel}

According to Gunn and Fewell (1993:63-68, 175-181), the narrative of Nebuchadnezzar and the three Jews (Dn 3) may be understood as an example of humour. They describe these passages as humorous on the basis of the narrator's style and love of the tedious detail, which sets a tone of ridicule and absurdity. Thus, through repetition the narrator pictures (and mocks) a setting in which conformity is the norm

2.The lovers compare each other to objects in nature. The comparisons include amongst others, that love is more delightful than wine (Can 1:2, 4; 4:10), the lover's name is like perfume (Can 1:3), she appears dark like the tents of Kedar or curtain of Solomon (Can 1:5), as a veiled woman (Can 1:7b), like a mare (Can 1:9), like a sachet of myrrh (Can 1:13), a cluster of henna (Can 1:14), eyes are doves (Can 1.15: $4 \cdot 1 \cdot 6 \cdot 9$ ), a rose of Sharon (Can 2:1) a lily (Can 2:1,2) an apple tree (Can 2:3), $1: 15 ; 4: 1 ; 6: 9$ ), a rose of Sharon (Can 2:1), a lily (Can 2:1,2), an apple tree (Can 2:3), a gazelle (Can 2:9, 17b), a young stag (Can 2:17c; 8:14), hair like a flock of goats (Can $4: 1 ; 6: 5 b$ ), teeth like a flock of sheep (Can $4: 2 ; 6: 6$ ), lips like scarlet ribbon (Ca $4: 3 a$ ), temples like halves of a pomegranate (Can 4:3b; 6:7), neck like tower of Davi (Can 4:4), breasts like two fawns, twin fawns of a gazelle, clusters of fruit or vine (Can 4:5; 7:3, 7a, 7b, 8), towers (Can 8:10), lips like honeycomb (Can 4:11), fragrance of clothes like Lebanon (Can 4:11), lover is a garden/spring/well (Can 4:12-16; 5:1) Comparison of the male lover: unlocking a door to allow her lover to enter a room (Can 5:4-6), head like gold (Can 5:11), hair black as a raven (Can 5:11), eyes like doves (Can 5:12), also like pools of Heshbon (Can 7:4), cheeks like spice (Can 5:13), lips like lilies (Can 5:13), arms rods of gold (Can 5:14), body like polished ivory (Can 5:14), legs pillars of marble/gold (Can 5:15a), appearance like Lebanon (Can 5:15b), mouth sweetness (Can 5:16). Comparison of woman to Tirzah or Jerusalem (Can 6:4), like the dawn/moon/sun/stars (Can 6:10), legs like jewels (Can 7:1), navel like grounded goblet (Can 7:2), waist is rounded wheat (Can 7:2), nose like tower of Lebanon (Can 7:4) head like mount Carmel (Can 7.5) hair like royal tapestry (Can Lebanon (Can 7:4), head like mount Carmel (Can 7:5), hair like royal tapestry (Can 7:5), stature like palm (Can 7:7a), fragrance of breath like apples (Can 7:8c), mouth like best wine (Can 7:9), like seal over heart or arm (Can 8:6). Thus a part of the main concern of book deals with statements comparing the lover to objects in nature.
Humour seems not in view.

3.Cf. Feinberg (1969:34-35), Brownlee (1986:74-75), Maarsingh (1985:56-59) and Eichrodt (1980:78-80). 
and disobedience unthinkable (Gunn \& Fewell ibid:175). However, apart from the possibility that ridicule and absurdity may be related to humour in some literature, the idea of repetition in the Old Testament serves as a way of emphasising statements - not the presentation of humour.

\section{God laughs}

Some suggest that the Bible probably accommodates humour, or perhaps inadvertently has found an important motivation for this possibility in passages that present God as laughing. For this reason, special attention will be given to four texts relevant to the problem, namely Psalms 2:4, Psalms 37:13, Psalms 59:9 (Eng v. 8) and Proverbs 1:26. These texts use the same verbal root for laughter on each occasion (śhq, cf. Ps 2:4; 37:13; 59:9 [Eng v. 8]; Pr 1:26). The question of whether God discloses humour will be restricted to a few notes on this lexeme as it appears and functions in the texts concerned and in relation to some of its synonyms. The main question to be answered is: Does the Old Testament depict God as acting and speaking in humorous terms or not? Thus, when dealing with the question of whether the Bible may be interpreted in humour terms, the reader is compelled to consider the main issue of this subject, namely the presentation of God as laughing.

\section{Psalms 2:4}

In all the texts involved (Ps 2:4, 37:13, 59:9 [Eng v. 8]; Pr 1:26), Yahweh, the God of Israel, is depicted as laughing. The same lexeme is used throughout to express God's laughter, that is, the conjugation of the root sihq, namely yișhaqq. The meaning of the term is determined by the lexeme on its own, and the literary or theological context of Psalms 2. Secondly, the reader will have noticed that yiśhāq (LXX: ekgelasetai < ekgelaō: 'laughs') in Psalms 2:4a is followed by the verb yil'ag (LXX: ekmuktēriei < ekmuktērizō: 'to hold in derision', 'to mock') in verse $4 \mathrm{~b}$ (and compare v11: $g y l$ ). In Psalms 37:13, yiśhaq (LXX: ekgelasetai) stands on its own and is not followed by any supporting term as in the case of Psalms 2:4. In Psalms 59:9 (cf. Ps 58:9), we find that tiśhaq (LXX: ekgelasē) is again followed by til'ag (LXX: exoudenōseis: < exoudenosōo: 'disdain', 'scorn'; cf. Ps 59[60]:14), as is the case in Psalms 2:4. In Proverbs 1:26, the same combination as in Psalms 2 and 59:9 appears, namely yiśhaq and til'ag (LXX: epigelasomai < epigelaō 'laugh' and katacharoumai < katachairō: 'to exult with malicious joy'; Pr 1:26). The meaning of yiśhaq and especially yil'ag as supportive lexeme of yiśhaq is important (Vischer 1966:131).

Spalding (1978:306), a well-known collector and author of Jewish humour, appeals to the Bible to substantiate his subject. Citing Psalms 2:4a ('He who sits in heaven laughs'), he accepts that even the Almighty has a sense of humour and concludes that 'if humour is good enough up there [in heaven] it ought to be good enough down here [on earth]'.

However, at least the following important exegetical factors seem to have been bypassed by Spalding regarding the depiction of God in this manner. Thus, to repeat, it is a wellknown prerogative that to understand an expression, the meaning of the relevant words must be determined first. The position of the word in the sentence, that is, its relationship to other terms in the sentence, and all relevant sentences and phrases adjacent to or around the text concerned must also be considered. The basic meaning of the word and the role of the context are decisive when determining the meaning of single terms.

The reference to God's laughter in the first part of the text (Ps 2:4a) does not represent a general statement about his attitude towards the phenomenon. The meaning of the concept is determined by:

1. the lexeme as such, which is laughter.

2. the word 'mocking' $\left(l^{\prime} g\right)$ in the second part of the text (Ps 2:4b)

3. additional statements in adjacent passages of the psalm.

The depiction of God, as seated in the heavens (Ps 2:4a), represents a sign of his superiority over his enemies dwelling on earth (Ps 4a, 10b). God laughs at (yiśhāq) or mocks the enemies of his anointed king (Ps 2:4b-6). Thus, God's laughter cannot be understood as humorous in character. God laughs at the incompetence of the enemies of his anointed king (Ps 59:9 [Eng v. 8]; Ps 37:13). He derides them as they often ridicule God's faithful followers (Ps 42:11; 79:4). God's laughter does not represent a jocular attitude. He considers the rebellion of his enemies as serious and therefore takes a stand against them as he does against sin (Ps 61:2; 78:31, 49; 106:40). Reference to God's anger also appears in Psalms 2:5 and 12 (Van Zyl 1989:590).

Any doubt, as to the nature of the laughter referred to in Psalms 2:4a, falls away when considering that the verb (plus preposition) in verse 2:4b, yil'ag-lāmô, without exception, carries the meaning of mockery or derision. The expression yiśhaq-lô in Psalms 37:13 has no parallel word reinforcing the latter term. However, Psalms 59:9 (Eng v. 8) acts as a companion text of Psalms 2:4, utilising the same combination of verbs as Psalms 2:4, that is, tiśhaq-lāmô // til'ag - a construction, which in turn is reinforced by Proverbs 1:26, namely'eśhāq // 'el'ag.

Thus, the mockery of the Old Testament is not confined to man. God does laugh, but not in a neutral way. God mocks the Egyptians (Ex 10:2; 1 Sm 6:6). God scorns the scorners (Pr 3:34; Brown 1978; cf. Kaiser 1981).

Again, according to Psalms 2:4, 'He who sits in heaven laughs (yiśhāq), the Lord holds them in derision' [ $\left.l^{\prime} g\right]$. The Jewish Midrash (par. 6 in Braude 1959:405, n. 15) on Psalms 2:4a apparently changed the verb of the Masoretic text (yiśhāq) from the qal to the pi'el form (yésaheq; Beuken 1961:129-130, and footnote 45). Since the pi'el can also act as a causative (Van der Merwe, Naude \& Kroeze 2004:80, [\$16.4.2]), Psalms 2:4a may be translated as follows: 'He who dwells in heaven causes them to laugh at each other' ('Jahweh doet hen lachen om 
elkaar'; Beuken ibid:130). This way the possibility of the Old Testament depicting God as laughing is further restricted.

Also, the laughter of God as stated in Psalms 2:4 does not represent a friendly gesture from his side. In fact, it expresses harsh and ominous laughter - an attitude that forebodes God's judgement. The fact that a reference to mockery follows the word laughter in Psalms 2:4 confirms that God's laughter implies a threatening character.

The latter is highlighted by the announcement of God that he will act in wrath (Ps 2:5) against the nations and their kings who rebel against him (Ps 2:1-3). In reaction to their rebellion against him and his anointed king (the latter empowered by his qualification and heritage; Ps 2:6-8), God will crush this revolt (Ps 2:9). Finally, the opposition is reprimanded warned against an ongoing insubordinate attitude - but also invited to submit to God's anointed. Those who adhere to these injunctions will be blessed (Ps 2:11-12).

\section{Psalms 37:13}

According to the psalm, the plans of the godless against the righteous will come to naught since God laughs at them; (yishaqa-lô; cf. Ps 52:8). He knows that the day of judgement is near. The phrase in question represents a threat. We thus have threatening laughter here, so to speak. Humour is not considered.

\section{Psalms 59:9 (Eng v. 8)}

The Lord laughs (tiśhaq-lāmô) at the wicked. He mocks (til'ag) all the nations. Again the two words appear together, and in the same order as in Psalms 2:4. Also, the second term qualifies the first - a fact that may be concluded from the surrounding texts in the psalm of God threatening the nations (cf. Ps 52:8).

The verb yiśhạq [He laughed] represents a colligative factor regarding the four texts: Psalms 2:4, 37:13, 52:8 and 59:9 (Eng v. 8). Also, two of the texts (Ps 2:4 and 59:9 [Eng v. 8]) contain the word mocking $\left(l^{\prime} g\right)$ following the term concerned, which thus qualifies the notion of laughter.

The phrase in Psalms 37:13 following the statement about laughter, namely 'because God foresees that his day will come', confirms the ominous character of the utterance. Elsewhere in the Old Testament this phrase refers to God acting against and punishing those who rise up against him and desert him (Ps 137:7; Ob 12).

\section{Proverbs 1:26}

Dame Wisdom (Pr 1:20) expresses concern by addressing the ignorant carrying on with their sinful lives. The words laugh ('eśhāq) and mock ('el'ag) follow the same order in Proverbs 1:26 as in the other passages referred to, namely 'laughing' followed by 'mocking'. Doubtless, Wisdom represents God's own voice and teaching - expressing reprimand, correction, admonition and reproof of the godless. In the cases commented on above and where the term śaha $q$ appears, it would seem that it does not represent the idea of carefree laughter.

Some are of the opinion (see Cox 1970:151) that this word (root: s'hq) may be translated as 'dancing' in Proverbs 8:30 (cf. v. 31: 'playing or dancing in the presence of God'). Gruber (1981) confirmed the meaning of silheq as 'dancing' by reading it in relation to 10 different Hebrew terms related to dancing. According to Keel (1974:25-30; cf. Keel \& Schroer 2008:220-223), the word concerned (méśaheqet) expresses Wisdom's playing (dancing) in the presence of God the Creator (Pr 8:30). Keel (1974:31-45, 46-62) also indicated that the term sitheq [play/dance] (cf. Pr 8:30ff.) gains graphical portrayal if studied against the background of ancient Near Eastern iconography.

Thus, the lexeme $(s / s h q)$ on occasion carries the meaning of 'playing' or 'dancing'. Compare the Israelites rising to play and dance in the presence of the golden calf (Ex 32:6), Samson playing before the Philistines (Jdg 16:25; 2 Sm 2:14; $6: 5,22 ; 1$ Chr 13:9; 15:29), David dancing in the presence of God (cf. 1 Chr 13:9, 15:29), and Wisdom playing or dancing before the creation and Creator ( $\operatorname{Pr} 8: 30,31$; Keel 1974:29-30). In none of these cases are there any hints to read the passages as humour.

Cox (1970:151), however, considers the references to David's notorious ritual 'dancing' before the Lord as disclosing humour. The passages in 2 Samuel 6:12, 15, 16, 20 and 21 refer to David's dancing before the Lord, but whether this action of David can be described as humorous is a moot point - especially in the light of David's wife, Michal, scorning him and his rude reaction towards her, namely punishing her with permanent childlessness. In addition, and in another sense, David's actions and behaviour in general are not to be followed or imitated, namely adultery (with Bathsheba) and murder (of her husband). Even if his behaviour in connection with the ark roused laughter, one can only wonder how that can be viewed as humorous. In contradiction to the latter incidents, it seems ironic that the name of Uriah the Hittite, husband of Bathsheba, is related to the idea of light, laughter and joy. The name may bear the meaning: 'YHWH is my light, joy and laughter.' Further, in Proverbs 10:23 the word carries a negative meaning, qualifying the action of the fool (who enjoys mischief) over against the wise. In contrast to these cases, the woman with integrity awaits each day laughing (Pr 31:25), thus not intimidated by problems.

According to Michel (1969), derision and its synonyms, such as the Hebrew verb based on the root qls [mock, scoff] and Greek 'empaizō [jest], represent expressions of contempt. In the Old Testament, mockery (and synonyms) as well as derision (and synonyms) served as instruments of conflict - usually between Yahweh or his prophets and Israel, the nations and the godless. Goldman (1952:2) suggested that the authors of the Bible realised in very early times that humour 
put a mighty weapon in their hands. Thus, on the one hand, verbal abuse is directed against Yahweh and his prophets (Is $28: 14 ; 29: 20)$. On the other hand, the prophets also attacked Israel's participation in the worship of idols (1 Ki 18:27; Is $44: 9 \mathrm{ff}$.).

However, it would seem that not only the prophets had to endure the constant scorn of Israel (2 Chr 36:11-16). The impious launched devastating onslaughts on the righteous in the form of slander (Ruppert 1973:110-148). Michel (1969) reminded readers that the Servant of the Lord had to endure mockery as part of his learning curve. This idea is carried forward to the New Testament, where Jesus Christ was subjected to the same humiliating action (Mk 10:34; 14:65; Jn 19:1-3; Mk 15:29-32; Lk 23:36; cf. 1 Cor 4:8-13).

\section{God shining or beaming}

Beuken (1961:117) indicated that Hellenistic religions laid great emphasis on their gods as laughing entities and that this was determined by different motives. According to Aristotle, the Greek gods were fond of a joke (Lloyd \& Mitchinson 2008:183). However, when Yahweh laughs, can one say that he is amused, or does he ridicule people? The former distinguishing feature finds no place in the Old Testament. On the contrary, in comparison with the Greek gods, who seem to be beaming with delight most of the time, the God of Israel is depicted as laughing only on occasion (Ps 2:4; 37:13; 59:9 [Eng v. 8]; Pr 1:26), and he is never pictured as laughing at the pious - only at the impious.

Beuken (1961:131-132) did not refer to humour in his discussion of laughter, but his conclusion on the matter of laughter is based on the decisive factor of the Greeks' concentration on the visual (seeing their gods), whereas in Judaism and Christianity the emphasis is on the auditory dimension and where seeing God will only become a reality in the eschatological era.

Beuken (1961:130) also pointed out that in contrast to laughter as practised by the Greeks, the Old Testament pictures believers as beaming or with radiant faces. They are cheerful, grinning, happy, joyful, smiling and sunny. Jeremiah 30:19 (cf. Jr 31:4) may serve as an example using the word méśahăqîm, based on the same root, șhq [the sound of rejoicing].

God is depicted as laughing, but in a different manner. Firstly, linking up with what was said above, it follows that the Old Testament presents God's benevolence in a manner that may be described as 'beaming' (beam approval, beaming forth, with joy, on someone). Accordingly, the light streaming from God's face represents a spiritual reality that may be described as the laughter of God. It is common practice in the Old Testament to use the phrase to shine upon, thus maintaining a direct reference to the qualification of 'light', in different forms (cf. the root: ' $w r$; Ps 31:16, 17; 67:1, 2; 80:3, 4, 7, 8; 119:135; Nm 6:25; Dn 9:17; also Ps 4:6, 7; 44:3, 4; 89:15, 16).
The Latin version (the Vulgate) also inclines in that direction (Beuken 1961:130).

\section{God rejoices}

God is sometimes depicted as rejoicing (e.g. Is 62:5: yāâîs; Is 65:19: wěgaltî, wěśaśtî). This observation may open a way to realise that God's rejoicing has laughter integrated with his reaction. This way, God's laughter may be understood as an expression of anthropomorphism.

Several texts bear witness to the reality that God rejoices (feel or express great joy or happiness). God rejoices over Judah-Israel when he restores his people and Zion (śwś/śyś: 'rejoice', 'to be glad', Dt 28:63; 30:9; Is 62:5; 64:4; 65:18-19; 66:10; Jr 32:41; Zph 3:17).

A few examples may serve as confirmation of this reality.

\section{gyl}

This word has often been used in connection with the gods rejoicing (e.g. Egypt). It has a variety of synonyms, for example śmh śyś/śiś (Barth 1977:469-475).

God appears as the subject of gyl in Isaiah 65:19 and Zephaniah 3:17, with reference to Jerusalem and the people of God. In addition to this reference, however, Zephaniah 3:17 strung together four different exclamations of God showing joy (rejoicing): gyl / / syś and śmh / / rnn respectively (Barth 1977:475), expressed in the typical literary form of parallelism.

\section{śmh}

About two-thirds of all occurrences of this root are found in theological contexts in the Bible. A substantial number of these are found in theological contexts in the narrower sense that they contain direct statements about God. Several synonyms are found either parallel to śmh or in the immediate context (Vanoni 2004:146).

In several texts (e.g. Job 22:19; Ps 35:19, 24; Pr 17:5; 1QpHab 4:1f.), the meaning of śm $h$ [rejoice] and $l^{\prime} g$ [mock] also overlaps. Isaiah 22:13 combines these two words in the typical manner: 'laughter' is followed by 'mock', thus lending a sombre taint to the phrase.

Psalms 104:31 and 34 present a case where the lexeme śmh expresses God's own joy in his works (yiśmah yhwh běma'ăśâyw). The Qumran War Scroll refers to 'the joy of God': śmht 'l (1QM 4:13-14; cf. Wise, Abegg \& Cook 2005:151-152; Vanoni 2004:157).

\section{śwś // śyś}

The verb appears eight times with a divine subject (two times in Dt 28:63; two times in Dt 30:9; Is 62:5; 65:19; Jr 32:41; Zph 3:17; cf. Fabry 2004:50). The roots gyl, hll, jdh, rnn and smh represent a confluence of the semantic content of the latter lexemes (Fabry 2004:51). 


\section{Summarising: Yahweh laughs and mocks}

Readers may have noted the prominence and gravity, and, particularly, the humourless character of utterances related to mockery or ridicule in the Old Testament. Attention has been drawn to texts that speak of God's laughter (Ps 2:4;37:13; 59:9). However, Yahweh is also personated as ridiculing his rivals, ${ }^{4}$ the foreign gods worshipped by Israel's neighbours (Preuss 1971:9-317, especially pp. 108-111 \& 146-151; Vischer 1966). On occasion, these people also led Israel astray to join in the worship of false gods. Yahweh regarded these so-called gods as worthless.

\section{Conclusion}

This article does not augur well for the conviction that the Old Testament contains material of a humorous character:

1 It would seem that most of the people who read the Bible take it as a matter of course that it accommodates humour.

2 The author of this article's personal view of humour (what is funny or what is not) glimmers through when comments are made in cases where contextual interpretation of the Bible is applied.

3 In cases where the meaning of lexemes is derived from their literary and theological contexts, it becomes clear that there is no indication of humour.

4 There are several terms in the Old Testament (e.g. $l^{\prime} g$ ) that are translated as 'mockery' or 'ridicule'. However, it is remarkable that even the word usually translated as 'laughter' (from the root $s h q$ and sh $h q$ ) also takes on the meaning of 'mockery' on occasion.

5 Freedman (1992:325-333) has pointed out that the Old Testament contains several words expressing laughing or laughter - whether in a spirit of goodwill or ridiculing someone, but he admits that the Hebrew Old Testament does not contain any word that can be translated as 'humour' as the concept is understood in contemporary Western society.

6 Thus, on the whole, laughter in the Old Testament shows an inclination towards mockery, language or behaviour intended to humiliate or despise - and not humour. It has become clear that some authors apply a hermeneutic of humour to selected biblical texts and/ or practise 'projection' hermeneutics by superimposing the idea of humour onto these texts, forcing the latter to ventriloquise. Exposition of a number of words, texts and passages proved otherwise.

7 Some references to laughter in the Old Testament are associated with God's own rejoicing and that of people in his presence.

\section{Acknowledgements Competing interests}

The author declares that he has no financial or personal relationship(s) that may have inappropriately influenced him in writing this article.

4.Cf. Isaiah $22: 13$ and 14 . In this text, "joy" occupies a parallel position with revelry (wantonness).

\section{References}

Aalders, G.Ch., 1955, Ezechiël: Hfdst. 1-24, vol. 1, J.H. Kok Uitgeversmaatschappij, Kampen.

Bartelmus, R., 2004, 'śāhaq/sāhaq', in G.J. Botterweck, H. Riggren \& H-J. Fabry (eds.), The Theological Dictionary of the Old Testament, transl. J. Bergman \& H. Ringgren, vol. 14, pp. 58-72, Eerdmans, Grand Rapids, MI.

Barth, Ch., 1977, 'gyl', in G.J. Botterweck, H. Riggren \& H-J. Fabry (eds.), The Theological Dictionary of the Old Testament, transl. J. Bergman \& H. Ringgren, vol. 2, pp. 469-475, , Eerdmans, Grand Rapids, MI.

Barth, Ch., 1997, 'lā'ag; la'ag; lā'ēg', in G.J. Botterweck, H. Riggren \& H-J. Fabry (eds.), The Theological Dictionary of the Old Testament, transl. J. Bergman \& H. Ringgren, vol. 8, pp. 10-14, Eerdmans, Grand Rapids, MI.

Berger, P.L., 1997, Redeeming laughter. The comic dimension of human experience, Walter de Gruyter, Berlin. http://dx.doi.org/10.1515/9783110810660

Beuken, W.A.M., 1961, ‘Goddelijke lach. Een vergelijkend onderzoek van de antieke literatuur en de Bijbel', Bijdragen 22, 117-132.

Braude, W., 1959, The Midrash on Psalms, transl. W. Braude, vol. 2, Yale University Press, New Haven.

Brown, F., Driver, S.R. \& Briggs, C.A., 1968, A Hebrew and English Lexicon of the Old Testament, The Clarendon Press, Oxford.

Brown, W.G., 1978, 'Mock, mocking', in M.C. Tenney (ed.), The Zondervan Pictorial Encyclopedia of the Bible, vol. 4 (M-P), p. 268, Zondervan, Grand Rapids, MI.

Brownlee, W.H., 1986, Ezekiel 1-19, Waco, Texas. (Word Biblical Commentary 28).

Claassens, L.J., 2008, 'Rigters', in F. Gaum (ed.), Christelike Kernensiklopedie, pp. 933-934, Lux Verbi.BM, Wellington.

Cox, H., 1970, The feast of fools: A theological essay on festivity and fantasy, 2nd edn., Harvard University Press, Cambridge.

Critchley, S., 2002, On humour, Routledge, London.

Daintith, J. \& Stibbs, A. (eds.), 1994, Bloomsbury treasury of quotations, Bloomsbury Publishing, London.

De Villiers, I.L., 2000, Die geluk van onsin. 'n Anderse kyk na dinge wat saak maak, Tafelberg Uitgewers, Kaapstad.

Eichrodt, W., 1980, Ezekiel:A commentary, SCM Press, London.

Fabry, H-J. (ed.), 2004, 'śwś śyś', in G.J. Botterweck, H. Riggren \& H-J. Fabry (eds.) The Theological Dictionary of the Old Testament, transl. J. Bergman \& $\mathrm{H}$. Ringgren, vol. 14, pp. 50-58, Eerdmans, Grand Rapids, MI.

Feinberg, C.L., 1969, The prophecy of Ezekiel: The glory of the Lord. A commentary, Moody Press, Chicago.

Freedman D.N. (ed.), 1992, The Anchor Bible Dictionary, vol. 3 (H-J), Doubleday/ HarperCollins, New York/Glasgow.

Gispen, W.H., 1979, Genesis II. Genesis 11:27-25:11, J.H. Kok Uitgeversmaatschappij, Kampen.

Goldman, M.D., 1952, 'Humour in the Hebrew Bible', Australian Biblical Review 2, 2-11.

Greenstein, E.L., 1992, 'Humour and wit in the Old Testament', in D.N. Freedman (ed.), The Anchor Bible Dictionary, vol. $3(\mathrm{H}-\mathrm{J})$, pp. 330-333, Doubleday, New York.

Gruber, M.I., 1981, 'Ten dance-derived expressions in the Hebrew Bible', Biblica 62, 328-346.

Gunn, D.A. \& Fewell, D.N., 1993, Narrative in the Hebrew Bible, Oxford University Press, New York. (The Oxford Bible Series).

Habel, N.C., 1985, The book of Job, SCM Press, London. (Old Testament Library).

Harrison, R.K., 1978, 'Humour', in M.C. Tenney (ed.), The Zondervan Pictorial Encyclopedia of the Bible, vol. 3 (H-L), pp. 224-226, Zondervan, Grand Rapids, $\mathrm{MI}$

Janzen, J.G., 1985, Job: Interpretation, John Knox Press, Atlanta.

Kaiser, W.C., 1981, 'la'ag', in R.L. Harris, G.L. Archer \& B. Waltke (eds.), Theological Wordbook of the Old Testament, vol. 1, pp. 480-481, Moody Press, Chicago.

Keel, O., 1974, Die Weisheit spielt vor Gott: Ein ikonographischer Beitrag zur Deutung des měśaheqet in Sprüche 8:30ff, Universitätsverlag/Vandenhoeck \& Ruprecht, Freiburg Schweiz/Göttingen.

Keel, O. \& Schroer, S., 2008, Schopfung: Biblische Theologien im Kontex altorientalsicher Religion, Fribourg Academic Press/Vandenhoeck \& Ruprecht, Fribourg/Göttingen.

Lloyd, J. \& Mitchinson, J., 2008, Advanced Banter: The QI book of quotations, Faber \& Faber, London.

Maarsingh, B., 1985, Ezechiël Deel I. POT, GF Callenbach, Nijkerk.

Michel, O., 1969, 'Bespotting', in B. Reiche \& L. Rost (eds.), Bijbels-Historisch Woordenboek, p. 226, I.A. Elim/Uitgeverij het Spectrum N.V., Utrecht/ Antwerpen.

Pierson, A.T., 1994, World's guide to understanding the Bible, AMG Publishers, Chattanooga, TN.

Preuss, H.D., 1971, 'Verspottung fremder Religionen im Alten Testament', Beiträge zur Wissenschaft vom Alten (und Neuen) Testament (BWANT), p. 92, Leipzig/ Stuttgart.

Rees, N., 2001, Cassell's humorous quotations, Cassell \& Co., London. 
Rengstorf, K.H., 1985, 'gelaō, katagelaō, gelōs', in G.W. Bromiley (ed.), The Theological Dictionary of the Old Testament, vol. 2, pp. 113-114, Eerdmans, Grand Rapids, MI.

Ruppert, L., 1973, Der leidende Gerechte und seine einde: eineWortfelduntersuchung, Echter-Verlag, Würzburg.

Sinclair, J.M., 1995, Collins English Dictionary and Thesaurus, HarperCollins Publishers, Glasgow.

Spalding, H.D. (ed.), 1978, A treasure-trove of American Jewish humour, Jonathan David Publishers, New York.

Stinespring, W.F., 1980, 'Humour', in G.A. Buttrick (ed.), The Interpreter's Dictionary of the Bible: Illustrated Encyclopedia, vol. 2 (E-J), pp. 660-662, Abingdon Press, Nashville.

Theron, P.F., 2004, 'The "God of war" and his "Prince of peace"', Dutch Reformed Theological Journal 45 (1\&2), 118-126.

Thielicke, H., 1975, Das Lachen der Heiligen und Narren: Nachdenkliches über Witzund Humor, Freiburger Graphische Betriebe, Germany. (Herderbücherei 491).

Van der Merwe, C.H.J., Naude, J.A. \& Kroeze, J.H., 2004, Biblical Hebrew Reference Grammar, Academic Press, Sheffield. (Biblical Language Hebrew 3).

Vanoni, G., 2004, 'śmh', in G.J. Botterweck, H. Riggren \& H-J. Fabry (eds.), The Theological Dictionary of the Old Testament, transl. J. Bergman \& H. Ringgren, vol. 14, pp. 142-157, Eerdmans, Grand Rapids, MI.
Van Selms, A., 1967, Genesis deel I \& II; De prediking van het Oude Testament Callenbach, Nijkerk.

Van Selms, A., 1983, Job II. POT, Callenbach, Nijkerk.

Van Selms, A., 1984, Job: Een praktische bijbelverklaring:Tekst en toelichting, Kok, Kampen.

Van Zyl, A.H., 1989, 'Die Psalms', in F.J. Botha, J.L. Helberg \& J.P. Oberholzer (eds.), Die Verklarende Bybel, bl. 586-683, Lux Verbi, Cape Town.

Vischer, W., 1966, 'Der im Himmel Thronende lacht. Freude am Evangelium', in F.S.A. de Quervain (ed.), Beiträge zur evangelische Theologie, vol. 44, pp. 129-135, Chr. Kaiser, Munich.

Von Rad, G., 1978, Genesis: A commentary, rev. edn., SCM Press, London.

Watts, J.D.W., 1985, Isaiah 1-33, Word Books, Waco, Texas. (Word Biblical Commentary 24).

Wenham, G.J., 1987, Genesis 1-15, Word Books, Waco, Texas. (Word Biblical Commentary 1).

Wise, M., Abegg, M. \& Cook, E., 2005, The Dead Sea Scrolls, HarperSanFrancisco, New York.

Zimmerli, W., 1979, Ezekiel I:A commentary on the book of the prophet Ezekiel. Chapters 1-24, Fortress Press, Philadelphia. 